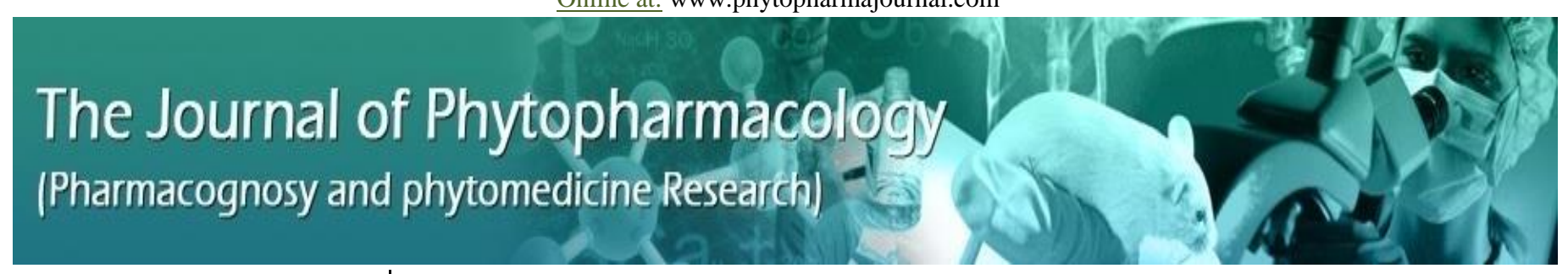

Review Article

ISSN 2320-480X

JPHYTO 2018; 7(3): 275-284

May- June

Received: $15-02-2018$

Accepted: 30-04-2018

(C) 2018, All rights reserved

Ndogo Eteme Olivier

a) Department of Chemistry, University of Yaoundé I, Yaoundé, Cameroon

b) School of Laboratory of Medicine \& Medical Sciences, University of KwaZulu-Natal, Durban 4001, South Africa

Nganso Ditchou Yves Oscar

Department of Chemistry, Faculty of Science, University of Maroua, Cameroon

Ndjie Louis

Molecular biology center of Yaounde, Cameroon

Nkoa Alima

Molecular biology center of Yaounde, Cameroon

Mbouma Goueth Françis

Department of Microbiology, University of Yaoundé I, Yaoundé, Cameroon

Nyasse Barthelemy

Department of Chemistry, University of Yaoundé I, Yaoundé, Cameroon
Correspondence:

Ndogo Eteme Olivier

a) Department of Chemistry, University

of Yaoundé I, Yaoundé, Cameroon

b) School of Laboratory of Medicine \&

Medical Sciences, University of

KwaZulu-Natal, Durban 4001, South

Africa

Email: leptit.neo[at]gmail.com

\section{Antibacterial properties of the extracts of Allexis obanensis and Allexis batangae (Violaceae) collected at Kribi (South Cameroon)}

Ndogo Eteme Olivier*, Nganso Ditchou Yves Oscar, Ndjie Louis, Nkoa Alima, Mbouma Goueth François, Nyasse Barthelemy

\section{ABSTRACT}

The present work presents the antibacterial activities of organic and aqueous extracts of Allexis batangae and Allexis obanensis (violaceae). These plants were collected in the locality of Kribi (South Cameroon). The leaf powder of these plants was cold extracted with a (1:1) methanol/methylene chloride mixture and hot extracted successively with hexane, ethyl acetate, and ethanol. Bark powder was cold extracted with methanol and hot extracted successively with hexane, ethyl acetate, and ethanol. The root powder was hot extracted with hexane, ethyl acetate, and ethanol. For distilled water extraction, only the leaf powder was extracted by maceration. The best yield was of the aqueous extract of leaves $(4.86 \%)$ and the lowest yield was obtained with the hexane extract of barks $(0.35 \%)$ for Allexis obanensis, the best yield was of the organic extract of leaves with ethanol $8.31 \%$ and the lowest value of the yield was obtained with the hexane extract of barks $0.81 \%$ for Allexis batangae. These extracts were subsequently submitted to the phytochemical screening which revealed that this plant is rich of flavonoids, alkaloids, sugars, lipids, phenol glycosides and saponins. The antibacterial test was performed using micro dilution method on five species of bacteria such as Escherichia coli, Enterobacter aerogenes, Enterobacter cloacae, Providencia stuartii, Klebsiella pneumonia, subdivided into nine strains including three ATCC reference strains and six clinical isolates. It flows from these tests that the bark and the roots of Allexis batangae present a great activity against these strains unlike leaves. Among the organic extracts, EA extract of bark and roots strongly inhibited eight strains out of nine, including CM64, BM67, ATCC8739, K2, PS299645, ATCC13048, EA289, ATCC11296 with MIC ranging between 31,2 $\mu \mathrm{g} / \mathrm{mL}$ to $250 \mu \mathrm{g} / \mathrm{mL}$. However, the EA294 strain was only weakly sensitive to EA extracts of bark and roots and not sensitive to other extracts. The EA extracts exhibited bactericidal activities on the most strains. The aqueous extract of leaves was inactive on all strains tested. For Allexis obanensis, the EA extract of leaves, the ethanol extract of barks and roots and the water extract of roots inhibited the growth of the bacterial tested. This inhibition was performed with MIC equal to 1000,250 and $125 \mu \mathrm{g} / \mathrm{mL}$. The most active extract was ethanol extract of roots. The sensibility of bacteria to these active extracts was below that of the reference drugCiprofloxacine. After determining the MBC of the extracts whose MIC were equal to 250 and $125 \mu \mathrm{g} / \mathrm{mL}$, the calculation of the ratio MIC to MBC discloses the bactericidal effect of the extracts. These results show that Allexis batangae and Allexis obanensis extracts can be used in therapy against bacterial infections.

Keywords: Allexis batangae, Allexis obanensis antibacterial activities, extraction, phytochemical screening.

\section{INTRODUCTION}

The infectious diseases, caused by the infectious agents such as the bacteria, have constituted for these last decades a true problem of public health ${ }^{[3]}$. The situation is much more alarming because of the appearance of the stocks of micro-organisms antibioresistants and the emergence of the noncommon infections ${ }^{[3]}$ which compromise the treatments with the existing drugs vis-a-vis these limits which the use of the antibacterials available presently in the market. In this context, it is essential to seek for new effective antibacterial substances, with broad spectrum of action. This research consists in looking to the plants for the development of new drugs. Indeed, World Health Organization (WHO) (WHO, 2002) estimates that, $80 \%$ of the African population always have recourse to the traditional medicine for which the major part of the therapies implies exploitation of the active ingredients of medicinal plants. Taking into account the importance of the plants species for public health, it is wise their scientifically study for a better use. The African vegetable flora is in general famous for its richness, because contains many vegetable species among which some already were scientifically studied and have led to drugs useful in primary care of health according to the WHO ${ }^{[3]}$. However, the flora of Cameroon although it is rich have been poorly studied with pharmaceutical objectives. Herein, the antibacterial properties of two plants belonging to the Violaceae family, Allexis batangae and Allexis obanensis, were evaluated in front of nine straints resistant to Gram negative. Violaceae plants have been constantly used by 
traditional medicine. Thus, the barks of Allexis cauliflora are used to treat fever and syphilis ${ }^{[1]}$. The bark of the Rinorea genus is used to calm the pain in women during childbirth and are also used to treat fever [37]. The roots of Hybanthus ipecuantha and Corynostylis hybanthus are used as emetic, as well as those of Anchietea salutaris, but also to treat sore throats and ganglionic tuberculosis ${ }^{[37]}$. The aerial parts of Viola tricolor are traditionally used in dermatological affections, acne, scarring and in oral hygiene, and orally this plant is indicated as antispasmodic and as antitussive [37]. A bibliography search on the Violaceae family has allowed to know that there are fewer phytochemical reports published on the genus Allexis to date. However, previous phytochemical studies on some species of other genera of the Violaceae family indicate the presence of potentially useful secondary metabolites such as flavonoids and triterpenoids ${ }^{[37]}$.

The present work will be organized around the three cornerstones: (i) preparation of the rough extracts (organic and aqueous); (ii) a phytochemistry screening of the extracts; and (iii) determination of the $\mathrm{CMI}$ and $\mathrm{CMB}$ of the extarcts.

\section{MATERIALS AND METHODS}

\section{Materials}

\section{Plant material}

The plants used in this work, namely Allexis batangae and Allexis obanensis, were collected on 7th June 2014 at Bidou II, $20 \mathrm{~km}$ from the town of Kribi (South Cameroon) under the leadership of M.NANA (Botanist). The identification was carried out at the National Herbarium of Cameroon by M.NANA in comparison with specimen number 31839 / HNC for Allexis batangae and sample number 49778 for Allexis obanensis.

\section{Botanical aspect}

Identified in Gabon and southern Cameroon (Kribi) in the Kienke forest, there are a small Shrub up to $6 \mathrm{~m}$ tall, with a pale brown smooth stem and small leaves. The flowering is done on the stem. It has pedicel fifteen millimeters long ${ }^{[1,2]}$.

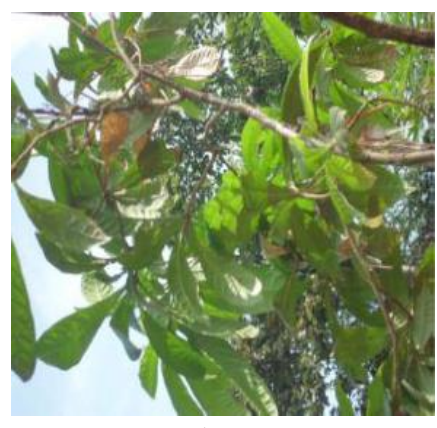

1

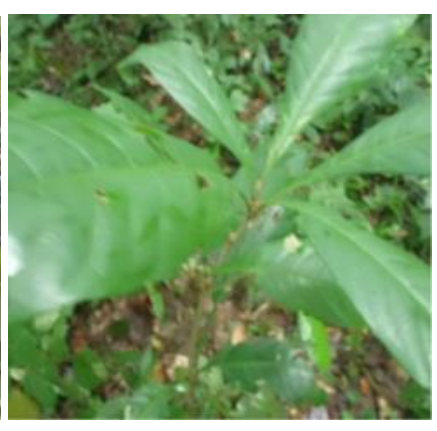

2
Figure 1: Allexis batangae (1) and Allexis obanensis (2) (pictures taken by OE. Ndogo, 2014)

\section{Bacterial strains used}

Nine strains of Gram-negative bacteria including reference strains (ATCC) and multi-resistant clinical isolates were used. These strains belonging to different bacterial species are distributed as follows:

- A strain of Escherichia coli (ATCC8739)

- A strain and three clinical isolates of Enterobacter aerogenes (ATCC13048; CM64; EA289; EA294)

- Two clinical isolates of Enterobacter cloacae (BM67,K2)

- A clinical isolate from Providencia stuartii (PS299645)

- A strain of Klebsiella pneumoniae (ATCC11296)

\section{Culture media}

Two cultures medias were used in this work:

- The Müeller Hinton Agar (MHA: Scharlau Chimie S.A., Barcelona, Spain) for the activation and the conservation of the bacteria.

- The Bouillon Müeller Hinton (MHB: Scharlau Chimie S.A., Barcelona, Spain) for the determination of MICs and CMBs.

\section{Antibacterial reference agent}

Ciprofloxacin was used as a standard antibiotic against bacteria. It is usually used in the treatment of bacterial infections and it acts by inhibiting the protein synthesis of the bacteria.

\section{Method}

\section{Extraction method on Allexis batangae}

\section{Organic extraction}

Sequential extractions were carried out for each part with solvents of increasing polarity following the same procedures (extraction test).

\section{The leaves}

Cold extraction: $400 \mathrm{~g}$ of leaf powder and were macerated in $2.5 \mathrm{~L}$ of $\mathrm{MeOH} / \mathrm{CH}_{2} \mathrm{Cl}_{2}(1 / 1)$.

Hot extraction: some quantities of leaf powder were extracted on sohxlet with these differents solvents: hexane, EA, EtOH as shown in the table1. All these extracts were concentrated with the rotary evaporator and dried in an oven.

\section{The barks}

For the cold extraction, $600 \mathrm{~g}$ of bark powder was macerated in $3.5 \mathrm{~L}$ of $\mathrm{MeOH}$. After obtaining the extract, some quantities of bark powder were extracted on sohxlet with these differents solvents: hexane, EA, $\mathrm{EtOH}$ as shown in the table1. All these extracts were concentrated with the rotary evaporator and dried in an oven.

\section{Aqueous extracts}

$750 \mathrm{~mL}$ of distilled water was added into $100 \mathrm{~g}$ of weighed-sheet powder using a precision balance and stirred occasionally. After 48 hours, the mixture was filtered with a white cloth and the filtrate carried in the centrifuge (Thermoscientific) at $6000 \mathrm{rpm}$ for decanting debris through the pores of the tissue. Subsequently, the filtrate was 
poured into the aluminum trays and placed in an oven (Roller grill) at $45^{\circ} \mathrm{C}$ for $48 \mathrm{~h}$. After total evaporation of the solvent, the extracts were scraped with a spatula and introduced into the flasks and then weighed and stored in a refrigerator at $4^{\circ} \mathrm{C}$.

\section{Extraction method on Allexis obanensis}

\section{Organic extraction}

Organic extraction was carried out sequentially as described above. The masses of powders used are given in Table 2.

\section{Aqueous extraction}

\section{Maceration}

Only the roots of the plant were macerated. $250 \mathrm{~mL}$ of distilled water were added of $50 \mathrm{~g}$ of roots powder. Stirred from time to time, the mixture was filtered after $48 \mathrm{~h}$ using a white cloth and the filtrate was brought into the centrifuge (Thermoscientific) at $6000 \mathrm{rpm}$ for decanting the debris having passed through the pores of the tissue. Subsequently, the filtrate was poured into the aluminum trays and brought to the oven (roller grill) at $45^{\circ} \mathrm{C}$. for $48 \mathrm{~h}$. After total evaporation of the solvent, the trays are scraped with a spatula and the extracts collected are introduced into the flasks and then weighed and stored in a refrigerator at $4^{\circ} \mathrm{C}$.

\section{Decoction}

The decoction was carried out with the leaves. In a beaker containing $750 \mathrm{~mL}$ of distilled water, $100 \mathrm{~g}$ of powder were added and boiled for 2hours. Using a white cloth the contents were filtered, centrifuged and subsequently poured into the aluminum trays and the same procedure was used as before.

\section{In vitro evaluation of the antibacterial activity of the crude extracts}

\section{Preparation of culture media}

\section{Solid medium}

$7.6 \mathrm{~g}$ of Mueller Hinton Agar (MHA) was dissolved in $200 \mathrm{~mL}$ of distilled water and then heated on autoclave at $121^{\circ} \mathrm{C}$ for $30 \mathrm{~min}$. After cooling the mixture was poured into the petri dishes near the beak of Bunsen.

\section{Liquid medium}

13.65 $\mathrm{g}$ of Mueller Hinton Broth (MHB) were dissolved in $650 \mathrm{ml}$ of distilled water. A part of this medium was distributed in tubes of $15 \mathrm{~mL}(10.853 \mathrm{~mL}$ per tube which will be used for inocula). Another part was distributed in the $2 \mathrm{~mL}$ tubes $(1.7 \mathrm{~mL}$ per tube for the dilution of the extracts). These tubes and the rest of medium were heated in an autoclave at $121^{\circ} \mathrm{C}$ for $30 \mathrm{~min}$.

\section{Culture of bacterial strains}

The different bacterial strains were subcultured by the method of the streaks on MHA agar medium poured into the Petri dishes. The petri dishes were introduced into the incubator at $37^{\circ} \mathrm{C}$. for 18 hours in order to obtain a young culture and isolated colonies. The isolated colonies were used to prepare the inoculum.

\section{Preparation of the inoculum}

Using a sterile platinum loop, a few colonies of bacteria from each strain were taken from the activation medium and each introduced into a tube containing a sterile physiological solution $(0.9 \% \mathrm{NaCl})$. The contents of each tube were homogenized using the vortex in order to obtain a turbidity comparable to the standard scale of Mc Farland (Table 1) corresponding to the concentration of 1.5. $108 \mathrm{CFU} / \mathrm{mL}$. Subsequently, $147 \mu \mathrm{l}$ of the resulting suspension was removed and introduced into $10.85 \mathrm{~mL}$ of MHB for a volume of $11000 \mathrm{~mL}$ of an inoculated medium at $2.10^{6} \mathrm{CFU} / \mathrm{mL}$.

\section{Preparation of stock solutions of crude extracts and reference antibiotic}

At least $8 \mathrm{mg}$ of the various extracts were dissolved in a volume of DMSO to obtain a stock solution of extracts with a concentration of $40 \mathrm{mg} / \mathrm{mL}$. This solution was diluted in the sterile culture medium (MHB), so as to have a concentration of $4 \mathrm{mg} / \mathrm{mL}$ of extract. For the reference antibiotic, at least $8 \mathrm{mg}$ was dissolved in DMSO so as to obtain a concentration of $4 \mathrm{mg} / \mathrm{mL}$ of stock solution which would be diluted in the medium to have a solution of $40 \mu \mathrm{g} / \mathrm{mL}$.

\section{Determination of MIC and CMB using the micro dilution method}

The micro-dilution method was used for this purpose according to the protocol described by [7]. $100 \mu \mathrm{l}$ of culture broth (MHB) were distributed in each well of the 96-well microtiter plates. Subsequently, $100 \mu \mathrm{L}$ of prepared extract solution was added to the first well of each column and serial and successive dilutions varying according to a geometric progression of reason 2 were made. The same procedure was used for the reference antibiotic which served as a positive control. Some wells containing the strain and culture medium served as a negative control. A volume of $100 \mu \mathrm{L}$ of bacterial inoculum was introduced into all wells, resulting in a final volume of $200 \mu \mathrm{L}$ per well, with a final inoculum concentration of $1.106 \mathrm{CFU} / \mathrm{mL}$. For the determination of the CMBs, after 18 hours of reincubation, $20 \mu \mathrm{L}$ of resazurin were introduced into these wells and reincubated for 4 hours. All concentrations of extract which prevented bacterial growth were considered as bactericidal concentrations, the smallest of which was noted as CMB Resazurin Revealing and Recording Results. The revelation was made by the colorimetric method using resazurin. Viable bacteria are colored pink in the presence of this solution. Compared to the negative controls, all concentrations that prevented the appearance of the pink color were considered to be the inhibitory concentrations, the smallest being the MIC or CMB. The classification of extracts of plant material on the CMI is as follows: Strong inhibition: MIC less than $500 \mu \mathrm{g} / \mathrm{mL}$ Moderate inhibition: MIC ranged from $500 \mu \mathrm{g} / \mathrm{mL}$ to $1500 \mu \mathrm{g} / \mathrm{mL}$

Low inhibition: MIC greater than $1500 \mu \mathrm{g} / \mathrm{mL}$. Parameters for the determination of bacterial inhibition CMI, CMB, CMB / CMI.

The CMI and CMB are two parameters for calculating the CMB/CMI ratio. This report makes it possible to characterize a bactericidal, bacteriostatic action or to determine the "tolerance" of a bacterial strain. 
The works of Berche (1993), Fauchère and Avril (2002), show that when the $\mathrm{CMB}$ of an antibiotic on a given strain is close to the MIC ( $\mathrm{CMB} / \mathrm{MIC}=1$ or 2$)$, the antibiotic is said to be bactericidal, in contrast, if these values are relatively distant ( 4 CMB / CMI > 16), the antibiotic is said to be bacteriostatic. Finally, if CMB / CMI $>32$, we speak of "tolerance" of the microbial strain.

\section{RESULTS}

Three types of results are obtained successively; We have raw extract yields, phytochemical tests and tests to determine inhibition concentrations of bacterial species sensitive to active extracts. Leaf powder will be extracted with organic solvents; before cold $\mathrm{MeOH} / \mathrm{CH}_{2} \mathrm{Cl}_{2}$ (1: 1), followed by hot extractions with hexane, ethyl acetate and ethanol. It will also undergo an aqueous extraction by maceration paralelly. In the case of Bark Powder, it will be extracted with organic solvents, first cold with $\mathrm{MeOH}$ and then hot as before. Root powder will be hot extracted as before.

\section{Extraction yield}

Tables 1 and 2 present the extraction yields of the various vegetable materials of Allexis batangae and obanensis.

\section{Phytochemical screening}

The results obtained from phytochemical analysis of each extract are summarized in Tables 3 and 4 .

\section{Antibacterial tests}

The tests of sensitivity of the bacterial stocks to the rough extracts (CMI and $\mathrm{CMB}$ in $\mu \mathrm{g} / \mathrm{mL}$ ) are consigned in tables 5 and 6 .

Table 1: Yield of various extractions of Alexis batangae

\begin{tabular}{lllll}
\hline & Extract & Mass dries (g) & Mass extract (g) & yield (\%) \\
\hline Leaves (cold extraction) & Extract $\mathrm{MeOH} / \mathrm{CH}_{2} \mathrm{Cl}_{2}(1 / 1)$ & 400 & 11 & 2,75 \\
Leaves (hot extraction) & Hexane & 730 & 14,1 & 1,92 \\
& Ethyl Acetate & 716 & 9,8 & 1,37 \\
& Ethanol & 706 & 33,4 & 4,73 \\
& Aqueous & 100 & 5 & 4,86 \\
Barks & MeOH & 600 & 7 & 1,17 \\
& Hexane & 593 & 2,1 & 0,35 \\
& Ethyl Acetate & 591 & 3 & 0,446 \\
& Ethanol & 588,2 & 12 & 2,02 \\
& Hexane & 880 & 4 & 0,443 \\
& Ethyl acetate & 876,1 & 3,5 & 0,396 \\
& Ethanol & 873 & 18 & 2,05 \\
\hline
\end{tabular}

Table 2: yield of various extractions of Allexis obanensis

\begin{tabular}{llll}
\hline Extracts & Mass extract obtained $(\mathbf{g})$ & Mass of initial powder $(\mathbf{g})$ & Extraction yield (\%) \\
\hline Leaves HEX & 34 & 920 & 3,69 \\
Leaves EA & 30,3 & 886 & 3,42 \\
Leaves meoh & 60 & 856 & 7,01 \\
Leaves etoh & 66,2 & 796 & 8,31 \\
Bark HEX & 4 & 480 & 0,81 \\
Bark meoh & 13,4 & 476,1 & 2,80 \\
Roots water & 44,8 & 1000 & 4,48 \\
Roots meoh & 1.20 & 50 & 2.4 \\
Leaves water & 3 & 100 & 3 \\
\hline
\end{tabular}

Table 3: Phytochemical screening of the various extracts of Allexis batangae

\begin{tabular}{|c|c|c|c|c|c|c|c|c|c|c|c|c|}
\hline & \multicolumn{5}{|l|}{ Leaves } & \multicolumn{4}{|l|}{ Barks } & \multicolumn{3}{|c|}{ Roots } \\
\hline & $\mathrm{MeOH} / \mathrm{CH}_{2} \mathrm{Cl}_{2}$ & Hex & EA & EtOH & water & МeOH & HEX & EA & EtOH & Hex & EA & EtOH \\
\hline Triterpenes & - & - & - & + & + & - & - & - & - & - & + & - \\
\hline Sterol & + & + & + & - & - & + & + & - & - & + & - & - \\
\hline Flavonoïdes & + & + & + & +++ & +++ & ++ & ++ & +++ & +++ & + & + & ++ \\
\hline Phenols & + & + & + & + & - & + & + & + & + & - & + & + \\
\hline Saponins & ++ & - & - & - & ++ & + & - & - & + & - & + & - \\
\hline
\end{tabular}




\begin{tabular}{|c|c|c|c|c|c|c|c|c|c|c|c|c|}
\hline Tanins & + & - & - & + & + & - & - & - & - & - & - & - \\
\hline Lipids & + & + & + & + & - & + & + & + & + & + & + & + \\
\hline Sugars & + & + & + & + & + & + & - & + & + & +++ & + & + \\
\hline Glycosides & + & + & + & + & + & + & + & + & + & + & + & + \\
\hline Alkaloids & ++ & + & ++ & ++ & + & + & - & + & + & - & +++ & + \\
\hline
\end{tabular}

Table 4: Result of the phytochemical screening Allexis obanensis.

\begin{tabular}{cccccccccccccc}
\hline & \multicolumn{1}{c}{ Leaves } & \multicolumn{1}{c}{ Barks } & \multicolumn{1}{c}{ Roots } \\
\cline { 2 - 7 } & MeOH/CH $\mathbf{C l}_{2}$ & Hex & EA & EtOH & water & MeOH & HEX & EA & EtOH & Hex & EA & EtOH \\
\hline Triterpens & - & + & + & + & + & - & - & - & - & - & + & - \\
Sterol & + & + & + & - & - & + & + & - & - & + & - & - \\
Flavonoïds & + & + & + & +++ & +++ & ++ & ++ & +++ & +++ & + & + & ++ \\
Phenols & + & + & + & + & - & + & + & + & + & - & + & + \\
Saponins & ++ & - & - & - & ++ & + & - & - & + & - & + & - \\
Tanins & + & - & - & - & + & - & - & - & - & - & - & - \\
Lipids & + & + & + & + & - & + & + & + & + & + & + & + \\
Sugars & + & + & + & + & + & + & - & + & + & +++ & + & + \\
Glycosides & + & + & + & + & + & + & + & + & + & + & + & + \\
Alkaloids & ++ & + & ++ & ++ & + & + & - & + & + & - & +++ & + \\
\hline
\end{tabular}

Table 5: CMI $(\mu \mathrm{g} / \mathrm{mL})$ of the various extracts on the nine stocks tested

\begin{tabular}{|c|c|c|c|c|c|c|c|c|c|c|}
\hline \multicolumn{2}{|c|}{$\begin{array}{ll}\text { Extracts } & \text { Strains } \\
\end{array}$} & CM64 & BM67 & ATCC 8739 & K2 & PS299 645 & ATCC 13048 & EA289 & ATCC 11296 & EA294 \\
\hline \multicolumn{2}{|c|}{ ciprofloxacine } & 0,156 & $<0,78$ & $<0,78$ & $<0,078$ & $<0,078$ & $<0,78$ & 0,156 & $<0,78$ & $<0,78$ \\
\hline Leaves & $\mathrm{MeOH} / \mathrm{CH}_{2} \mathrm{Cl}_{2}$ & - & - & - & - & 1000 & - & - & - & - \\
\hline \multirow[t]{4}{*}{ Leaves } & Hexane & 500 & - & 500 & 1000 & - & - & - & - & - \\
\hline & EA & 500 & 1000 & 250 & 500 & & 1000 & 1000 & 1000 & - \\
\hline & ethanol & - & - & - & - & - & - & - & 500 & - \\
\hline & water & - & - & - & - & - & - & - & - & - \\
\hline \multirow[t]{4}{*}{ Barks } & $\mathrm{MeOH}$ & 250 & 500 & 250 & 125 & 1000 & 250 & 500 & 250 & - \\
\hline & hexane & 1000 & 1000 & 1000 & 1000 & 1000 & 1000 & - & 1000 & - \\
\hline & EA & 62,5 & 31,2 & 31,2 & 62,5 & 125 & 31,2 & 62,5 & 31,2 & 1000 \\
\hline & ethanol & 1000 & 1000 & 1000 & 500 & - & 500 & 1000 & 500 & - \\
\hline Roots & hexane & 1000 & - & - & - & 1000 & - & - & - & - \\
\hline \multirow[t]{2}{*}{ Roots } & EA & 125 & 62,5 & 125 & 62,5 & 125 & 125 & 250 & 250 & 1000 \\
\hline & ethanol & 500 & 500 & 500 & 250 & 1000 & 250 & 1000 & 1000 & - \\
\hline
\end{tabular}

$(-)=>1000 \mu \mathrm{g} / \mathrm{mL}$

Analysis of Table 5 reveals that the MIC of the hexane extracts varies from 500 to $1000 \mu \mathrm{g} / \mathrm{mL}$. The EA extracts of the barks and roots of Allexis batangae, which give the best CMI results, were further investigated for the $\mathrm{CMB}$. The $\mathrm{MeOH}$ extract of the bark has a MIC ranging from 125 to $1000 \mu \mathrm{g} / \mathrm{mL}$ and the $\mathrm{MeOH} / \mathrm{CH}_{2} \mathrm{Cl}_{2}$ extract from the leaves is inactive on all strains except for PS299645 where the MIC is $1000 \mu \mathrm{g} / \mathrm{mL}$. The ethanolic extracts of the three parts of the plant, namely leaves, barks and roots, have a MIC of between 250 and $1000 \mu \mathrm{g} / \mathrm{mL}$. The aqueous leaf extract does not inhibit the growth of any strain. 
Table 6: CMB of the bark and root extracts of the nine strains tested and the CMB / CMI ratio

\begin{tabular}{|c|c|c|c|c|c|c|c|c|c|c|}
\hline Extracts & $\begin{array}{l}\text { Parameters bacterial } \\
(\mathrm{CMB} \text { in } \mu \mathrm{g} / \mathrm{mL} \\
\text { and } \mathrm{CMB} / \mathrm{CMI})\end{array}$ & CM64 & BM67 & ATCC 8739 & K2 & PS299 645 & ATCC 13048 & EA289 & ATCC 11296 & EA294 \\
\hline \multirow[t]{2}{*}{ EA barks } & CMB & 62,5 & 125 & 62,5 & 62,5 & 250 & 62,5 & 125 & 62,5 & - \\
\hline & $\mathrm{CMB} / \mathrm{CMI}$ & 1 & 4 & 2 & 1 & 2 & 2 & 2 & 2 & - \\
\hline \multirow[t]{2}{*}{ EA roots } & $\mathrm{CMB}$ & 250 & - & - & 62,5 & - & 250 & 500 & 500 & - \\
\hline & $\mathrm{CMB} / \mathrm{CMI}$ & 2 & - & - & 1 & - & 2 & 2 & 2 & - \\
\hline
\end{tabular}

Results indicated in Table 6 shows that the CMB / CMI ratio of the EA extract of the bark varies between 1 and 2 for strains: CM64, ATCC8739, K2, PS299645, ATCC13048, EA289, ATCC11296 and is equal to 4 for strain BM67. While the CMB / CMI ratio of the root extract AE varies from 1 to 2 for strains CM64, K2, ATCC13048, EA289, ATCC11296.

Table 7: Results of the antibacterial activity of Allexis obanensis extracts

\begin{tabular}{|c|c|c|c|c|c|c|c|c|c|}
\hline Extracts & CM 64 & BM 67 & ATCC 8739 & $\mathbf{K 2}$ & PS 299645 & ATCC 13048 & EA 289 & ATCC 11296 & EA 294 \\
\hline CIPROLOXACINE & 0,156 & $<0,78$ & $<0,78$ & $<0,078$ & $<0,078$ & $<0,78$ & 0,156 & $<0,78$ & $<0,78$ \\
\hline LEAVES HEX & $x$ & $x$ & $x$ & $x$ & $x$ & $x$ & $x$ & $x$ & $x$ \\
\hline LEAVES EA & 1000 & 1000 & $x$ & 1000 & $x$ & $x$ & $x$ & 1000 & $x$ \\
\hline LEAVES MeOH & $x$ & $x$ & $x$ & $x$ & $x$ & $x$ & $x$ & $x$ & $x$ \\
\hline LEAVES WATER & $x$ & $x$ & $x$ & $x$ & $x$ & $x$ & $x$ & $x$ & $x$ \\
\hline LEAVES EtOH & $\times$ & $\times$ & $\times$ & $\times$ & $\times$ & $\times$ & $x$ & $x$ & $\times$ \\
\hline BARKS HEX & $x$ & $x$ & $x$ & $x$ & $x$ & $x$ & $x$ & $x$ & $x$ \\
\hline BARKS EtOH & 250 & 250 & 125 & 1000 & $x$ & $x$ & $x$ & 125 & $x$ \\
\hline ROOTS EtOH & 250 & 250 & 250 & 1000 & 1000 & 250 & 250 & 125 & $x$ \\
\hline ROOTS WATER & $x$ & 1000 & $x$ & $x$ & $x$ & $x$ & $x$ & $x$ & $x$ \\
\hline
\end{tabular}

Legend: $x=$ negative result

Analysis of this table indicates that the antibiotic Ciprofloxacin inhibits all bacterial strains at a very small MIC, less than $0.7 \mu \mathrm{g} / \mathrm{mL}$. Hexane, methanol and water decoction extracts have no effect on the bacterial strains and clinical isolates used, as well as certain ethanolic extracts such as leaf extracts. The leaf extract with ethyl acetate inhibited four clinical isolates and one strain (CM 64, BM 67, K 2, ATCC11296) to very high MICs equal to $1000 \mu \mathrm{g} / \mathrm{mL}$. Only the ethanolic extract of the bark inhibits 2 strains and three clinical isolates with MICs equal to: $1000 \mu \mathrm{g} / \mathrm{mL}$ for isolate $\mathrm{K} 2,250 \mu \mathrm{g} / \mathrm{ml}$ for isolates

CM 64 and BM 67 and $125 \mu \mathrm{g} /$ ML for strains ATCC 8739, ATCC 11296. For roots, ethanol extract inhibits all strains and all clinical isolates except EA 294 isolate and aqueous extract with water maceration inhibits only Strain BM 67.

Table 8: CMB results on Allexis obanensis

\begin{tabular}{|c|c|c|c|c|c|c|c|c|c|}
\hline $\begin{array}{l}\text { Extracts } \\
\text { Strains }\end{array}$ & CM 64 & BM 67 & ATCC 8739 & K2 & PS 299645 & ATCC 13048 & EA 289 & ATCC 11296 & EA 294 \\
\hline BARK EtOH & 500 & 250 & 250 & ND & ND & ND & ND & 250 & ND \\
\hline ROOTS EtOH & 500 & 500 & 250 & ND & ND & 500 & 500 & 250 & ND \\
\hline
\end{tabular}

Analysis of table 8 , it arises that the CMB obtained are equal to 250 or $500 \mu \mathrm{g} / \mathrm{mL}$. It should be noted that, only the most active extracts
(CMI less than or equal to $250 \mu \mathrm{g} / \mathrm{mL}$ ) were used for given the CMB. 
Table 9: Result of ratio CMB/CMI

\begin{tabular}{llllllllll}
\hline STRRACT & CM 64 & BM 67 & ATCC 8739 & K2 & PS 299645 & ATCC 13048 & EA 289 & ATCC 11296 & EA 294 \\
\cline { 3 - 3 } & 0.5 & 1 & 0.5 & ND & ND & ND & ND & 0.5 & ND \\
ROOTS EtOH & 0.5 & 0.5 & 1 & ND & ND & 0.5 & 0.5 & 0.5 & ND \\
\hline
\end{tabular}

Caption: $\mathrm{ND}=$ not determined

From the analysis of Table 9, it was found that the CMB / CMI ratio of the ethanolic extract of the bark had a bactericidal effect on the isolates CM 64 and BM 67, strains ATCC 8739, ATCC 11296; The ethanolic extract of the roots also has a bactericidal effect on all the clinical strains and isolates used with the exception of PS.

\section{DISCUSSION}

The antibacterial activities of the leaves, barks and roots of Allexis obanensis, extracted with water and organic solvents reveals that taking into consideration both strains Bacterial and the seven clinical isolates used, all were sensitive to at least one extract with MICs equal to 1000,250 and $125 \mu \mathrm{g} / \mathrm{mL}$ except for one clinical isolate (EA 294). This distinct sensitivity of strains to extracts in liquid medium is due to the fact that the sensitivity of a microorganism to a plant extract depends mainly on the composition of the extract, but also on the microorganism itself and the environment in which it takes place the action ${ }^{[13]}$.

Overall, the results obtained showing moderate to good activity taking into account that there are extracts. At this stage of the project, it does not make any sense to perform a direct comparison with Ciprofloxacin, which is used as positive control. The extracts as the own name indicates are mixtures of compounds, some with activity, some with less or no activity, and with possibility of negative synergistic effects. The absence of antibacterial activity observed with organic extracts of leaves and barks with hexane, with methanol and with ethanol (only for leaves) and aqueous leaf extract with water decoction could be explained by the absence or low concentration of certain secondary metabolites known as active ingredients. The results of the MICs of the organic extracts show that only the ethyl acetate extract of the leaves of Allexis obanensis and the ethanolic extracts of the barks and were active on the bacterial strains and clinical isolates used. Leaves EA extract inhibited three isolates out of the six and one bacterial strain out of all three, with a MIC of $1000 \mathrm{Mg} / \mathrm{ml}$. The low activity of this extract could be due to the absence of tannins and saponins and the presence of all other compounds. But the leaves $\mathrm{Hex}$ and $\mathrm{MeOH}$ extracts having the same composition as the leaves EA, we do not know that extracts are inactive on the bacterial strains and clinical isolates used, this would be due to the fact that hexane and methanol extract chlorophyll from the leaves, Other photosynthesis substances that interact with secondary metabolites and therefore reduce their ability to inhibit antibacterial activity. Ethanol extracts inhibit more strains and clinical isolates. In addition to the strains and isolate inhibited by the leaves of Allexis obanensis EA extract, barks of Allexis obanensis EtOH extract inhibits another bacterial strain (ATCC 8739); This would be caused probably by the presence of tannins in this extract. Tannins possess toxic activity against bacteria ${ }^{[63]}$. The antimicrobial activity of tannins is due to their ability to complex to transport proteins ${ }^{[63]}$. The roots of Allexis obanensis EtOH extract inhibits all bacterial strains and clinical isolates used with the exception of the EA294 isolate. The sensitivity of the bacteria to this extract would be due to the presence of saponins and tannins which are absent simultaneously in the other extracts which have been active on the bacteria. In addition to the tannins whose antimicrobial activity has been justified, saponins also have antimicrobial properties, in fact, the therapeutic potential of saponins against bacteria is linked to the membrane permeability of the complex that it forms with ${ }^{[5,46]}$. The observation of the results of phytochemical screening of aqueous extracts calls into question the action of the saponins and tannins justified above. This could be explained on the one hand by the higher extraction yield for organic extractions than for aqueous extractions and on the other hand by the secondary metabolite composition of the extracts. In fact the extracts of the leaves of Allexis obanensis with water decoction and roots with water maceration contain tannins and saponins but only the root water maceration extract was active and inhibited a single clinical isolate then the simultaneous presence of tannins and saponins is not sufficient for the antibacterial activity of Allexis obanensis. The inhibitory activity of Allexis obanensis is probably due on the one hand to the presence of tannins and saponins that bind to the lipids in order to enter the microorganisms ${ }^{[5]}$ and on the other hand to the presence Triterpenes and sterols. These metabolites possess antimicrobial properties against resistant bacteria ${ }^{[41]}$ and are perharps responsible for the bactericidal effect of bark of Allexis obanensis $\mathrm{EtOH}$ and roots of Allexis obanensis EtOH extracts. Indeed, terpenoids are known to induce apoptosis ${ }^{[60]}$, tannins induce leakage of potassium ions at the level of the bacterial membrane and therefore a precursor effect for their death ${ }^{[51]}$. The microbiological tests have not yet been done on Allexis obanensis so we cannot compare our results with other work. However, the inhibitory activity of triterpenes, tannins, saponins and lipids on the bacterial species showed the antibacterial activity of these secondary metabolites on the bacterial species that we used ${ }^{[38]}$. The resistance of several human pathogenic species to many antibacterial substances and the traditional use of medicinal plants for the treatment of microbial infections are the motivations underpinning this study whose overall objective was to evaluate the antibacterial properties Organic and aqueous extracts of leaves, barks and roots of Allexis obanensis. From this work it emerges that only a clinical isolate has been resistant to organic and aqueous extracts of leaves, barks and roots of Allexis obanensis. Furthermore, the ethanolic extracts of bark and roots EtOH have a bactericidal effect on the bacterial species used. The bioactive metabolites responsible for the inhibitory and bactericidal activity of the extracts would be tannins, saponins, lipids, triterpenes andsterols. Evaluation of the antibacterial activities of the organic crude extracts revealed that eight of the strains tested, namely CM64, BM67, ATCC8739, K2, PS299645, EA289, ATCC13048, ATCC11296, were extremely sensitive to EA extracts from leaves, barks and roots of Allexis batangae. The EA extract was very active with the lowest MIC ranged between 31.2 and $500 \mu \mathrm{g} / \mathrm{mL}$ on almost all strains tested. This result corroborates the classification of Aligiannis ${ }^{[4]}$, according to which an extract has a strong inhibition of strains when its MIC is less than $500 \mu \mathrm{g} / \mathrm{mL}$. This could be explained by the fact that this solvent extracts in a large quantity the compounds capable of inhibiting the growth of the strains, unlike the other solvents which 
extract them, but in a small amount, for which they possess moderate antibacterial activity (ethanolic extract of the roots) See low (hexane extract of the bark for most strains and roots only for CM64, PS299645, as well as the MeOH / DCM extract of leaves on strain PS299645). Among the extracts of the three parts (leaves, barks, roots), it was mainly those of the bark which inhibited the growth of the strains, this could be explained by the fact that it is at the bark level that a large Quantity of secondary metabolites with antibacterial activities. The mechanisms of action of the active ingredients can vary from one species to another and also from one strain to another. This observation would also be justified by the lack of sensitivity of the EA294 strain to all the crude extracts except those at the bark and root EA which showed a low antibacterial activity $(1000 \mu \mathrm{g} / \mathrm{mL})$ on this strain. Moreover, this non-sensitivity could also be justified by the fact that the antibacterial molecules present in the extracts were not sufficiently concentrated to inhibit the growth of this bacterium. All active extracts have a MIC greater than that of the reference antibiotic (ciprofloxacin), so the sensitivity of these strains to these extracts is lower than that of ciprofloxacin, this could be explained by the fact that the active ingredient Would be present in small amounts in these extracts, since the extracts are mixtures of compounds whereas ciprofloxacin is a pure, isolated molecule. The absence of antibacterial activity observed with the aqueous extract of the leaves is characteristic and suggests a low concentration of bioactive molecules that cannot inhibit the growth of bacterial species. When the CMB of an antibiotic on a given strain is close to the MIC (CMB / CMI $=1$ or 2), the antibiotic is said to be bactericidal, if these values are relatively far apart (4 <CMB / CMI> 16), the antibiotic is said to be bacteriostatic. Finally, if CMB / CMI> 32, we speak of "tolerance" of the microbial strain ${ }^{[5]}$. The extract EA of the bark is bactericidal on the strains: CM64, ATCC8739, K2, PS299645, ATCC13048, EA289, ATCC11296 and bacteriostatic on the BM67 strain. The root extract EA is bactericidal on strains CM64, K2, ATCC13048, EA289, ATCC11296. The majority of strains and clinical isolates were sensitive to extracts except the isolate EA 294 which was not sensitive to any extract. The wall of all the bacteria contains polymers of glycans which are crosslinked by a pentapeptide whose sequence is generally attached to the sugar; This crosslinking gives the cell its rigidity and its mechanical strength ${ }^{[13]}$. The strong resistance of EA 294, one of the clinical isolates of Enterobacter aerogenes, is due, on the one hand, to a very high crosslinking of polymers of glycans to pentapeptides and, on the other hand, to a sharp reduction in the synthesis of non-specific porins and the presence of a very active efflux pump ${ }^{[40]}$. All this reduces the penetration of the extract into the cell.

\section{CONLUSION}

The obtained results confirm and validate the traditional use of some of these plants, which could be good sources and alternative of metabolites for anti-TB-drug development. These encouraging results prompted us to pursue the evaluation of the most active extracts. Therefore, fractionation and further phytochemical and pharmacological studies of these plants are evidently worthy, and our group is focusing on this effort.

\section{Acknowledgement}

All thanks to Higher Institute of Agriculture and Management of Obala for material and financial supports.

\section{REFERENCES}

1. Achoundong G. The African genus Allexis (Violaceae). A synoptic revision, National Herbarium. 2010, 9p.

2. Achoundong et Onana JM. Allexis zygomorpha (Violaceae): a new species from the littoral forest of Cameroon. Kew Bulletin, 1998; 53(4):1009-1010.

3. Akoua KC, Guessend N, Gbonon V, Faye-kette AYH, Dosso M. Methicillini-resistant of $S$. aureus activity in Abidjan: A new hospital problem. Medecines Maladies Infectieuses, 2004; 34(3):132-36.

4. Aligiannis N, Kalpotzakis E, Mitaku S, Chinou IB. Composition and antimicrobial activity of the essential oils of two Origanum species. Journal of Agricultural and Food Chemistry. 2001; 40:4168-4170.

5. Arabski M, Węgierek-Ciuk A, Czerwonka G, Lankoff A, et Kaca W. Effects of Saponins against Clinical E. coli Strains and Eukaryotic Cell Line. Journal of Biomedicine and Biotechnology. 2012; 6:3.

6. Audoin Boudon I, Richard A, Prévost C, Brongniard A. Dictionnaire Classique d'Histoire Naturelle. Eds Baudoin Frères, Paris 2003, pp4.

7. Barnes BJ, Wiederhold NP, Micek ST, Polish LB, et Ritchie DJ. "Enterobacter cloacae ventriculitis successfully treated with cefepime and gentamicin: case report and review of the literature". Pharmacotherapy, 2003; 23(4):537-542.

8. Baron S. Medical Microbiology. 4th edition, Galveston. 1996; $17 \mathrm{p}$.

9. Baron S, Jennings PM, Peterson JW. Medical microbiology.4ed, Baron s, eds California, 1986; pp: 256-158.

10. Bassez M-P. La biodiversité des milieux extrêmes. Université de Strasbourg. IUT Robert Schuman 2010; 49p www.fetedela science.fr seen 28/10/2014.

11. Berche P, Gaillard JL, Simonet M. Bactéries des infections humaines. Collection de la Biologie à la Clinique, Ed MédécineSciences Flammarion, 1989 ; pp: 106-108, 232-236, 267-274, 593-600.

12. Bourgeois A. Les MST/SIDA au Cameroun. Biodiagnostic and therapy. Magasine bilingue de santé au Cameroun NoO04 Comité de l'Antibiogramme de la Société Française de Microbiologie (CA-SFM), édition de Janvier 2010, 49 pages.

13. Breukink et Kruijff, Lipid II as a target for antibiotics. Nat. Rev. Drug Discov., 2006; 5(4):321-322.

14. Brooks GF, Butel JS, Morse SA, Jawetz Melnick. et Adelberg. Medical Microbiology. 23rd Ed, Singapore. 2004; pp: 167-168.

15. Bruneton J. Pharmacognosie et phytochimie des plantes médicinales. 3ème Ed Tec \& Doc., Paris, 1999; pp. 101-120.

16. Cos P, Vlietinck AJ, Berghe DV, et Maes L. Anti-infective potential of natural products: How to develop a stronger in vitro proof-of-concept. Journal of Ethnopharmacology. 2006; 106:290-302.

17. Cowan MM. Plants products as antimicrobial activity. Clinical Microbiology Reviews, 1999; 12(4):564-582.

18. Davin A, Monnet D, Saux P, Bosi C, Charrel R, Barthelemy A. et Bollet C. Molecular epidemiology of Enterobacter aerogenes acquisition: one-year prospective study in two intensive care units. Journal of Clinical Microbiology. 1996; 34:1474-1480.

19. de Souza C, Amegavi KK, Koumaglo K, et Gbeassor M. Étude de l'activité antimicrobienne des extraits aqueux totaux de dix plantes médicinales. Revue de Méd et Pharmaco afr, 1993; 7:109-115. 
20. Djahra AB. Etude phytochimique et activité antimicrobienne, anyioxydante, et antihépatotoxique du Marrube blanc ou Marubium vulgare. Thèse de Doctorat, 2014, 114 p.

21. Dubreuil L. Méthodes d'études de la sensibilité aux antibiotiques des bactéries anaérobies stricts. Revue Française de Laboratoire, 1993; 256:91-98.

22. Emurawa AC. Antibacterial substance [rom Carica papaya fruit extracl. Journal of Natural Products. 1982; 45:123-127.

23. Encyclopédie universalis. France SA, Paris, 2008; pp 473, 747, 758-759.

24. EVAN B. Infection treatment and medication, 2009. http://emedicine.medscape.com/article/226541-overview seen 06/11/2014.

25. Fiorucci S. Activités biologiques des composés de la famille de flavonoïdes: approches par des méthodes de chimie quantique et de dynamique moléculaire. Thèse de doctorat, Nice, 2008, 211p.

26. Ford RA, Hawkins DR, Mayo BC, et Api AM. The in vitro dermal absorption and metabolism of coumarin by rats and by human volunteers under simulated conditions of use in fragrances. Food and Chemical Toxicology, 2001; 39:153-162.

27. Ghestem A, Seguin E, Paris M, et Orecchioni AM. Le préparateur en pharmacie, Dossier 2 Botanique-PharmacognosiePhytotherapie-homeopathie. Tec et Doc (Ed), 2001; pp 272.

28. Guillemot D, Maugendre P, Vhauvin et Sermé TC. Consommation des antibiotiques en France. BEH 2004; 3233:141-147.

29. Harbone JB. Phytochemical methods. A guide of modern techniques of plants analysis. Chapman and Hall, London, 1976, pp 150 .

30. Hutsinson J, et Dalzin JM. Flora of West Tropical Africa. 2nd edition, prown agents for overseas, London, 1954; pp 264-281.

31. Kaboré ZI, et Millogo Koné H. Étude antibactérienne in vitro d'extraits alcaloïdiques de Holarrhena floribunda (Apocynaceae) vis a-vis d'Escherichia coli Entéropathogène, Sérotype 0127. Revue Pharmacopée et Médecine traditionnelles africaines, 1997; IX:17-23.

32. Kanneth T. Bacillus and related endospore-forming bacteria. Textbook of Bacteriomogy, 2008; pp. 102-104.

33. Kil HY, Seong ES, Ghimire BK, Chung IM, Kwon SS, et al. Antioxidant and antimicrobial activities of crude sorghum extract. Food Chemistry, 2009; 115:1234-1239.

34. Kouokan C, Lahs T, et Becher H. Antimicrobial activity of the essential oil and some isolated sulfur-rich compounds from Conodophloeus zankeri. Planta Medica, 2002; 68:1082-1087.

35. Larpent JP. et Larpent-Gourgaud M. Éléments de microbiologie. Collection Enseignement des sciences, Ed Hermann, Paris, 1985, pp.146.

36. Li HB, Cheng KW, Wong CC, Fan KW, Chen F, et Tian Y. Evaluation of antioxidant capacity and total phenolic content of different fraction of selected microalgae. Food Chimestry, 2007; 102:771-776.

37. Lune HI, Lee J, Zee OP. et Chung JH. Un isoflavonoïde glycosidique de Viola hondoensis W. Becker et H. Boissieu (Violaceae), et son effet sur l'expression de la matrice métalloprotéinase-1 causée par le rayonnement ultraviolet dans les fibroblastes de peau humaine cultivés. Biol. Pharm. Bull., 2005; 28:1123-1125.

38. Mabeku Kouitcheu B, Kouam J, Penlap V, Ngadjui B, Fomum Z T, et Etoa X F. Evaluation of Antimicrobial Activity of the Stem Bark of Cylicodiscus Gabunensis (Mimosaceae). In Afr. J. Tradit. Complement Altern Med. 2007; 4(1):87-93.
39. Macheix JJ, Fleuriet A. et Jay-Allemand C. Les composés phénoliques des végétaux: un exemple de métabolites secondaires d'importance économique. Ed Presses polytechnologiques et universitaires romandes, 2005, pp 4-5.

40. Mallea M, Mahamoud A, Chevalier J, Alibert-Franco S, Brouant $\mathrm{P}$, Barbe J. et Pages JM. Alkylaminoquinolines inhibit the bacterial antibiotic efflux pump in multidrug-resistant clinical isolates. Biochemical Journal. 2003; 376:801-805.

41. Mamta S, Jyoti S, Rajeev N. Dharmendra S. et Abhishek G., Phytochimie des plantes médicinales. Journal de pharmacognosie et phytochimie. $2013 ; 1(6): 168$.a.

42. Meyer A, et Deiana J. Cours de microbiologie général. Doin éditeurs, Paris. 1988; pp. 201-224, 234.

43. Meyer A, Deiana J. et Bernard A. Cours de microbiologie générale: avec problèmes et exercices corrigés. Collection biosciences et techniques, Doin éditeur, 2004; 2ed., pp 238, 240.

44. OMS, Maladies infectieuses en Afrique. Situation et perspectives d'action. 7ème Réunion du forum pour le partenariat avec l'Afrique, Moscou, Russie, 2006, 19 p.

45. Oliver. Flora of Tropical Africa. 1867; I:111.

46. Omulokoli E, Khan B. et Chhabra SC. Antiplasmodial activity of four Kenyan medicinal plants. Journal of Ethnopharmacology. 1997; 56:133-137.

47. Oussou KR, Yolou S, Boti JB, Guessennd KN, Kanko C, Ahibo C. et Casanova J. Étude chimique et activité antidiarrhetique des huiles essentielles de deux plantes aromatiques de la pharmacopée ivoirienne. European Journal of Scientific Research. 2008; 24(1):94-103.

48. Pebret F. Maladies infectieuses: toutes les pathologies des programmes officiels des études médicales ou paramédicales. Heures de France, Paris, 2003; pp. 58-64.

49. Peronny S. La perception gustative et la consommation des tannins chez le maki (Lemur catta). Thèse de doctorat, 2005, $151 \mathrm{p}$.

50. Pierre. Allexis in Bull. Soc. Linn, Paris, Nouv. Ser., 1898, 25 p.

51. Rhayour K. Etude du mécanisme de l'action bactéricide des huile essentielles sur E.coli, B. subtilis, sur M. philui et M. fortuitum. Thèse de Doctorat, Maroc, 2002, 158 p.

52. Reynaud J. et Lussignol M. The flavonoids of Lotus corniculatus. Lotus Newsletter, 2005; 35:75- 82.

53. Sathish Kumar M, Selvakumar S, Rao MRK. et Anbuselvi S. Preliminary phytochemical analysis of Dodonaea viscose leaves. Asian Journal of plant science and research. 2013; 3(1):43-46.

54. Scalbert A. Antimicrobial properties of tannins. Phytochemistry, 1991; 30:3875-3883.

55. Singleton P. et Sainsbury D. Chapitre 11. In Bacteriologie, Edition Masson, 1984, pp 119- 129.

56. Sirot D, Sirot J, Labia R, Morand A, Courvalin P. et DarfeuilleMichaud A. Transferable resistance to third generation cephalosporins in clinical isolates of Klebsiella pneumoniae: identification of CTX-1, a novel bêta-lactamase. Journal of Antimicrobial and Chemotherary. 1987; 20:323-333.

57. Soro D, Koné MW, Kamanzi AK. Evaluation de l'activité antibactérienne et anti-radicale libres de quelques taxons bioactifs de Côte d'Ivoire. Europ. J. Sci. Res. 2010; 40:307-317.

58. Stefanova T, Nikolova N, Michailova A, Mitov I, Iancovii, Zlabinger GI, Neychev H. Enhanced resistance to Salmonella enteric sero var typhimurium infection in mice after coumarin treatment. Microbes and infection, 2007; 9:7-14.

59. Stern JL, Hagerman AE, Steinberg PD. et Mason P. K. Phlorotannin protein interactions. Journal of Chemical Ecology. 1996; 22:1887-1899. 
60. Tapiero H, Tew KD, et Mathé G., Polyphenols: do they play a role in the prevention of human pathologies? Biomedecine and pharmacotherapy, 2002; 56(4):200-207.

61. Tenover FC, PhD. Mechanisms of Antimicrobial Resistance in Bacteria. The American Journal of the Medical sciences. 2006; 119(6A):S3-S10.

62. Thangara JHS, Adjei O, Allen BW, et Portaels F. In-vitro activity of ciprofloxacin, sparfloxacin, ofloxacin, amikacin and rifampicin against Ghanian isolates of Mycobacterium ulcerans. Journal Antimicrobial Agents Chemoter, 2000; 45(2):231-233.

63. Scalbert A. Antimicrobial properties of tannins. Phytochemistry, 1991; 30:3875-3883.

\section{HOW TO CITE THIS ARTICLE}

Olivier NE, Oscar NDY, Louis N, Alima N, François MG, Barthelemy N. Antibacterial properties of the extracts of Allexis obanensis and Allexis batangae (Violaceae) collected at Kribi (South Cameroon). J Phytopharmacol 2018; 7(3):275-284. 